\title{
Considerations of Regional Coherences for the Development of Renewable Energy Technologies Used in South Part of Transdanubian Region of Hungary
}

\author{
Zoltan Illes ${ }^{1}$, Peter Szendro ${ }^{2, *}$, Janosne UnK ${ }^{3}$
}

\begin{abstract}
The existing effective domestic regional development framework requires analyses for increasingly wider areas (micro, meso and even macro regions) before operational - short-term - local developments to be prepared and implemented.

Such comprehensive complex studies or larger-term programmes may demonstrate the profitability of the given project and can complement it with combined utilization technologies; in the case of Himesháza several locally known renewable energy sources could facilitate geothermal heat, later electricity supply, e.g. local biomass (biogas-based) recovery technology (organic waste of the local pig farm) and, for example, the construction of a low-power "dwarf" hydroelectric power plant chain based on rich watercourses of the region (the "southern dwarves" in Hungary) and the connection of existing solar utility facilities to a modern "smart grid" system in the longer term.

Himesháza, located in southern Hungary in Baranya county, is developing; it has a detailed feasibility study of a thermal energy supply network and an energy supply development plan.
\end{abstract}

Based on the geothermal characteristics of Baranya county it would be reasonable to encourage the development of smaller-scale, decentralized heating systems for dynamic settlements. Several settlements in close proximity to Himesháza have already explored thermal wells. Power generation with a small scale, closed-loop system can be used in the project region for thermal water with an outflow temperature of $90{ }^{\circ} \mathrm{C}$. The heating system may also be able to fulfill the needs of recreational, vacation-based or complex thermal spa facilities formerly planned in the region. Moreover, the system could also be capable of utilizing a larger spectrum of renewable energy through its combination with photovoltaic technology.

Due to the country's favorable agricultural characteristics, Hungary's biomass potential is higher than the European average. The utilization of organic waste from agricultural and farming sectors is highly recommended in Baranya county; biogas production seems to be the most suitable in the region of Himesháza too, broadening the utilization of renewable resources.

The realization of the current project could contribute to shifting the energy resource sector in a more modern, environmentally conscious direction.

*Corresponding author. E-mail address: szendro.peter@gek.szie.hu

${ }^{1}$ Department of Environmental Sciences \& Policy, Central European University

(CEU), H-1051 Budapest, Nádor u. 9, Hungary

${ }^{2}$ Szent Istvan University (SZIE), Godollo

${ }^{3}$ Energy Development, Urban and Regional Development Institute (VATI), Budapest 
The background for shorter-term plans and investment (carried out within the framework of operational programs) necessary for the optimal operation and maintenance of longer-term (25-50 years) energy development strategies is created by the analysis (at multiple scales) of complex regional characteristics and future potential, and the selection of optimal sites.

Keywords: renewable energy, geothermal, biomass, hydroelectric, solar

\section{Principles and objectives}

- First and foremost, the protection of the natural environment

- Improving living conditions locally, and generally

- Exploring and preferring local renewable energy resource potential

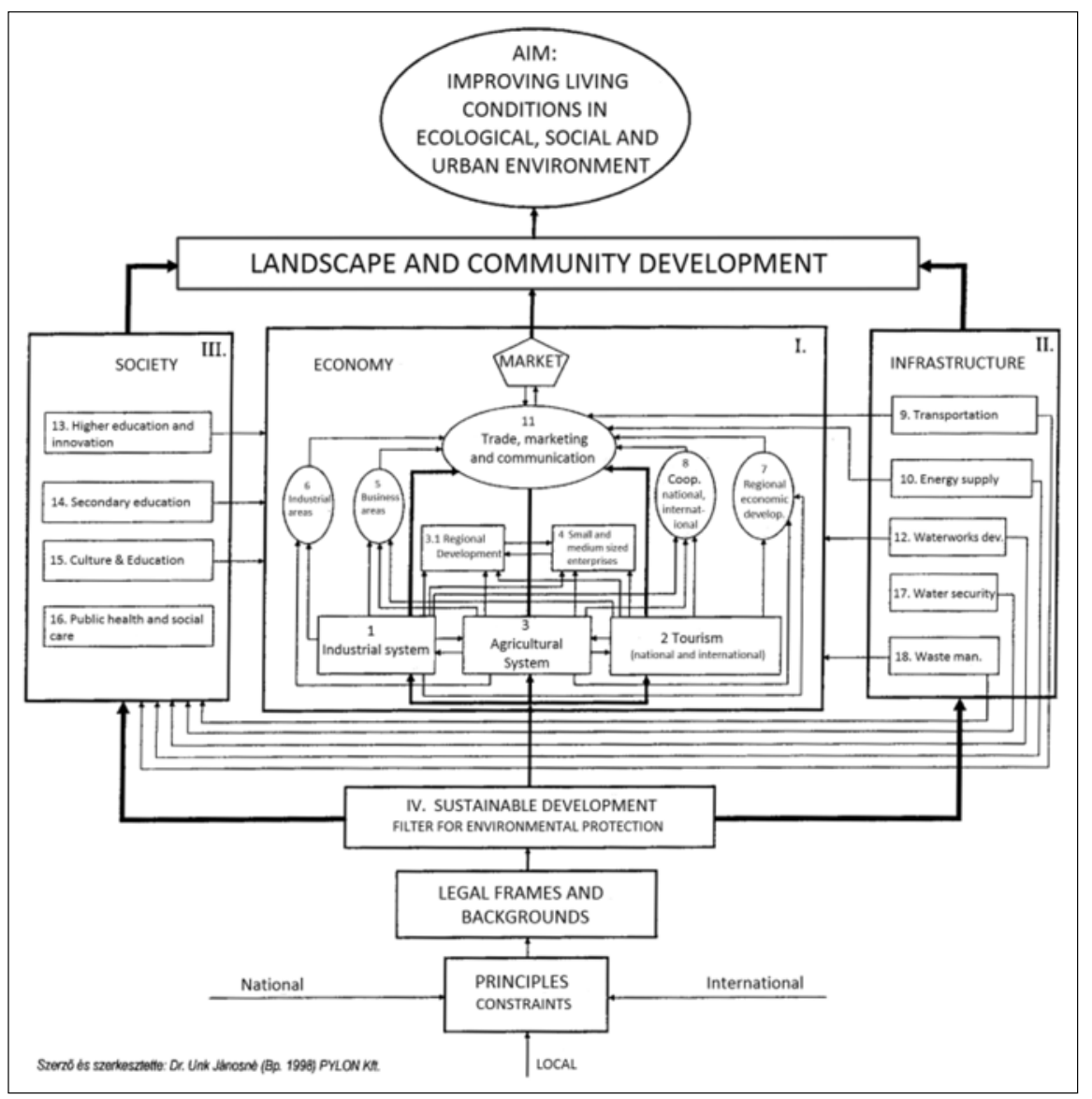

Fig. 1. Conceptual model of the framework and connections of the regional development program [1] 
- Developing technologies for renewable utilization

- Validating goals like energy-saving and energy-efficiency

- Protecting and conserving the regional natural environment and its components [according to the respective laws: $1^{*}, 2^{*}, 3^{*}, 4^{*}$, EU Directives: $5^{*}, 6^{*}$, Government decrees in 2017-2019: $\left.7^{*}, 8^{*}\right]$

From the aforementioned objectives, the first is considered to be the most important, according to which all developments must go through the filter of environmental protection, meaning that their fate and sustainability must depend on such criteria in line with the new-from-old perspective. The complex system of connections demonstrated through and applied - continuously updated - to the example under analysis (Fig. 1) embraces a wide range of cases of social, economic and infrastructural developments in a given region, showing their mutual connections and dependencies [1]. The model developed in 1998 is still valid.

\section{Regional development programs}

Based on the National Development Plan (Nemzeti Fejlesztési Terv) that characterizes the goals and priorities for Hungary in all relevant fields and sectors (economy, society and environment) for longer term, development plans were also carried out on a regional level (Regional Operation Programs - TOP). In order to proceed further for the realization of the goals, the more detailed Integrated Regional Development Programs (ITP) needs to be accomplished on county level, for mid-term (2014-2020). These should include not only the regional goals but the application of financial support, expected results and timelines. The one for Barany county was carried out in 2017 [4]. Priority 5 of the ITP for Baranya county states that the "Facilitation of foundations of a 'climatically conscious' environmental management based on the sustainable use of natural resources." This connects to, and hence supported by the TOP Priorities 2 and 3 [4]. Congruence between the national directions, goals, and the regional priorities is essential that insures the realization of the long term visions.

\section{Structure and components of regional energy systems within the spatial structure of Hungary}

Regional energy systems make up an important part of the regional development plans and the spatial plans of any area - country, region, county and settlement - that include both the functional spatial system (social and economic environment) and the technical and physical system (infrastructure), in which: 
- energy is the basis and requirement for all spatial activity

- they closely interact with all sectors of the economy, while energy is an essential ingredient of the functional setting of regions

- energy production and distribution systems are interlinked with the economy and infrastructural systems, along with:

- traditional types of energy resources - coal, oil, gas, uranium fields

- the locations for harnessing and converting renewable energy (the potential for solar, wind, ocean and hydropower, geothermal, and biomass primary, secondary and tertiary energy resources) (Figure 2)

- networks of different approaches to energy supply; including in detail:

- settings for oil supply and oil products (grids and refineries)

- settings for gas supply (purifiers, containers, distribution systems for different scales, the compression stations and gas transmission equipment of national and international networks)

- the settings and elements of electricity supply (power stations, pipeline networks for national and international cooperation and transformation stations) and low-medium voltage electricity distribution systems

- plant for the transmission and utilization of renewable energy and the related networks and connecting systems (traditional and smart grid)

\subsection{Current varieties of renewable energy resources and different technologies for its utilization}

Globally - thus also in Hungary - renewable energy resources utilized directly or indirectly come from two main sources, the sun and the Earth, and their classification has been defined in relation to these sources since the 1970s [5]. These groups and their means of utilization have been broadening (into more subgroups in terms of utilizing the energy of the sun and the Earth) due to technological and other reasons, as shown in Fig. 2.

\subsection{Different approaches to energy supply and integrating systems regarding technology and infrastructure}

An analysis of the technology and infrastructure connected to the energy networks of the Central-Eastern European region draws attention to those regions with underdeveloped networks. A more detailed analysis had to be further focused and carried out on all units of energy supply, such as the national oil and gas supply network, national electricity network systems, 


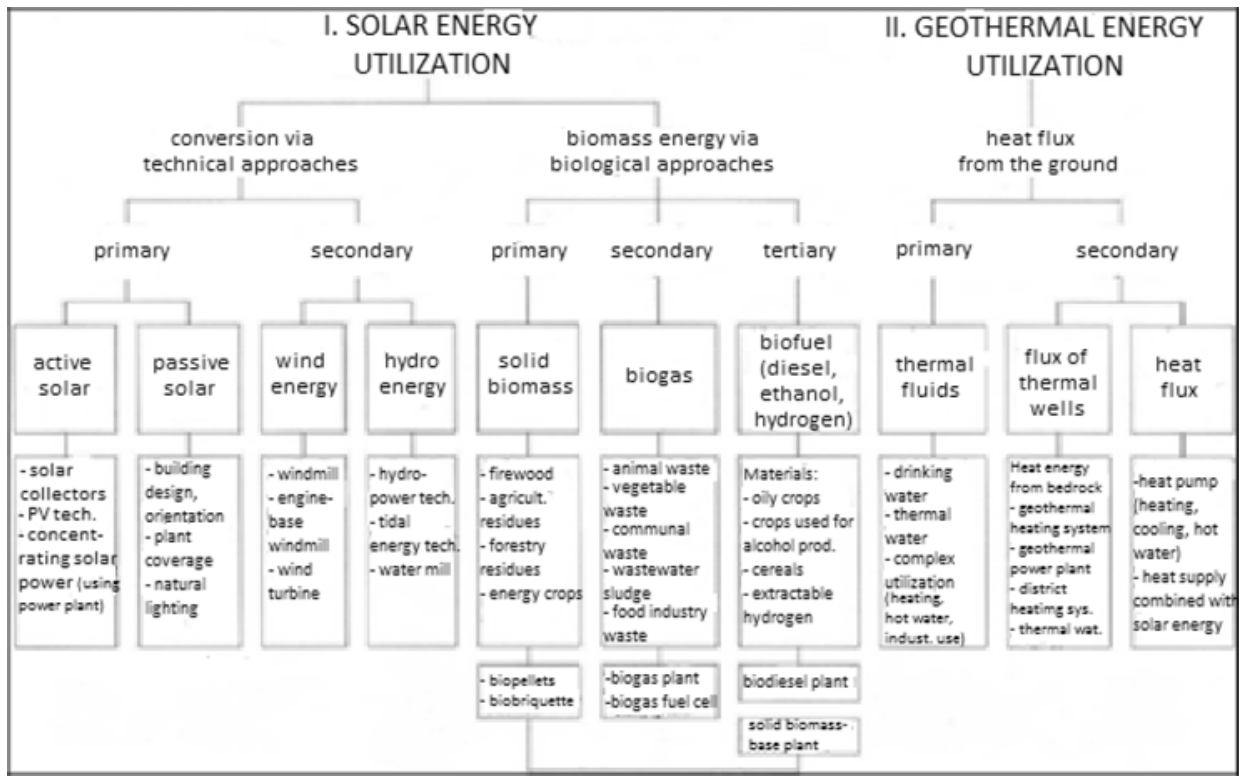

Fig. 2. Classification of renewable energy resources in Hungary based on the known approaches of utilization $[1,5]$

national transmission systems with the main distribution points $(132 \mathrm{kV}$; see Fig. ${ }^{1}$ ), and local and regional transmission and supply network systems (Fig. 4).

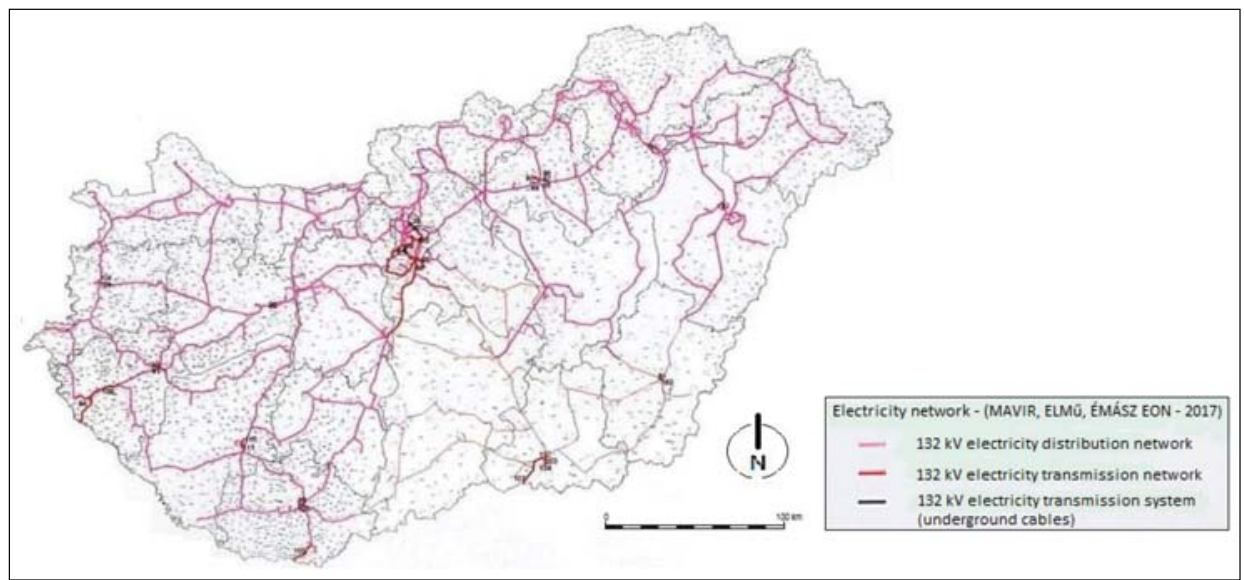

Fig. 3. Electrical energy supply network of Hungary, the main distribution and transmission network (from 2017)

1 All maps in the paper are in North-South orientation. 


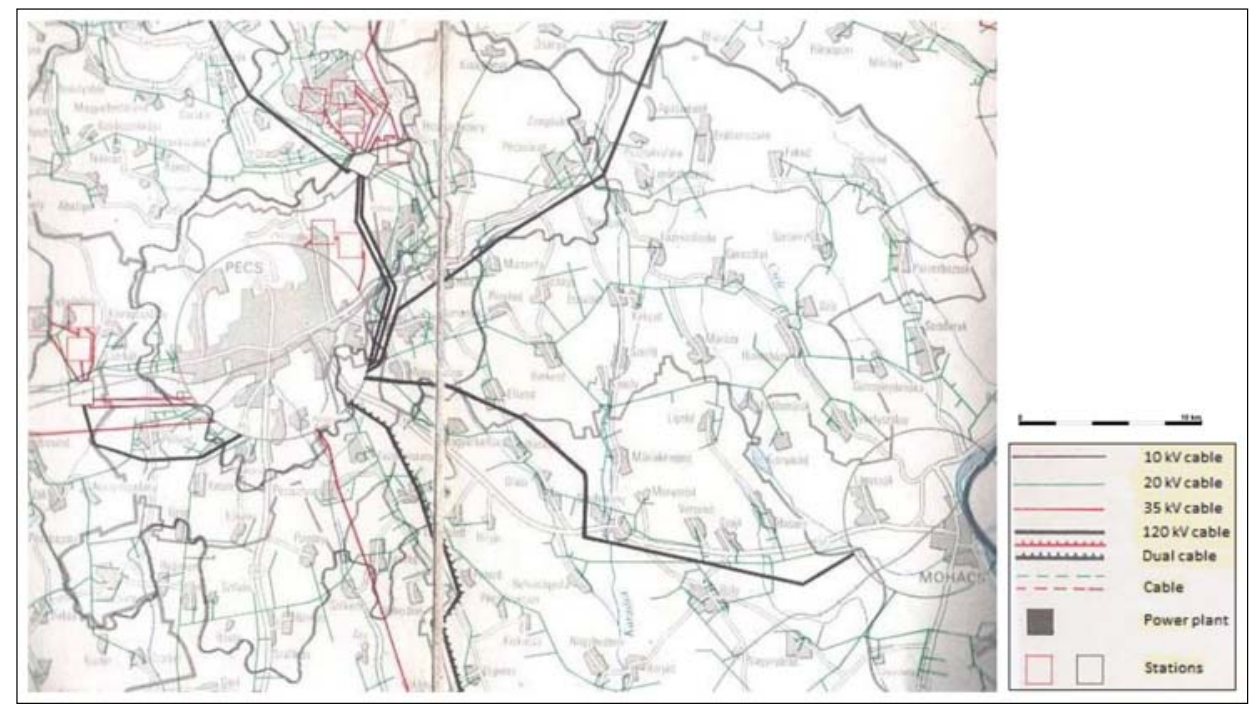

Fig. 4. Section of the electrical energy supply network in region of Himesháza-MohácsPécs-Komló-Bátaszék

The section of the trail of the distribution network of overhead lines in the examined region $(20 \mathrm{kV})$ is shown in Fig. 4 according to the records of the regional electricity supplier of South-Transdanubia (MVMT Dél-Dunántúl). On the map the missing sections of the overhead lines necessary for bilateral feeding are clearly visible and also the missing section of power lines $(132 \mathrm{kV})$ between Mohács, Himesháza and Bátaszék.

In Hungary in the future, alongside the centralized electricity systems which span the entire country and facilitate integration into the international network and trading-marketing services, low-voltage electricity distribution networks are supposedly going to increase in value (not only economic value). These networks and their integration need to be developed according to the needs of local consumers in the wake of such a paradigm shift.

Namely, since the nineteenth century the global trend has been to develop large, continent-wide, high-voltage electricity networks $(1000 \mathrm{kV}, 750 \mathrm{kV}$, $400 \mathrm{kV}, 120 \mathrm{kV}$ ) and the high-capacity power plants for their supply that are associated with large investments and extended and expensive power line networks. These trends have rather neglected the development and maintenance of the medium- $(20-10 \mathrm{kV})$ and low-voltage $(0.4 \mathrm{kV})$ electricity supply networks that actually reach consumers. This trend is about to change (local restructuring) and the latter networks are going to become the local networks for production and supply. The current condition of these networks is on average underdeveloped and outdated; a large portion of the lines work in 
a radial manner rather than in a more desirable "loop" system where resistance is bilateral.

Looking at future scenarios, a highly important and manageable task, even in mid-term, is to start developing smart-grid and virtual micro-grid systems. Such systems are able to receive the electricity produced from various, small-scale sources in a region such as a settlement, and to manage its storage, control, regulation, distribution, and connection to the regional supply network. Security is not overlooked but essential in these systems. In such a way, the system contributes to a local supply network and coordinates its sections. There are two means of operating for these systems: they can operate as part of a conventional network system (low- and mid-voltage), or they can work independently of the regional/national grid. This approach to local, decentralized networks is going to steadily revolutionize the conventional system of electricity production and distribution.

"Task: to develop a municipal electricity supply network with a geothermal basis, supported by the TOP tender; to demonstrate its sustainability and potential for future up-scaling based on the results of larger regional research using the case of Himesháza and its surrounding area."

\section{The site of the TOP development plan}

Himesháza is located in southern Hungary in the South Transdanubian region, or more precisely, in Baranya county in the "Mohács" sub-region (Figs 5, 6). The current population is 1,028 people (in 2017), the number of households is 448; inner settlement area $203 \mathrm{ha}$, and total settlement area $1,150 \mathrm{ha}$. The proportion of households connected to the drinking water supply is $90 \%$, those connected to the gas network is $75 \%$; the wastewater disposal system is up to date.

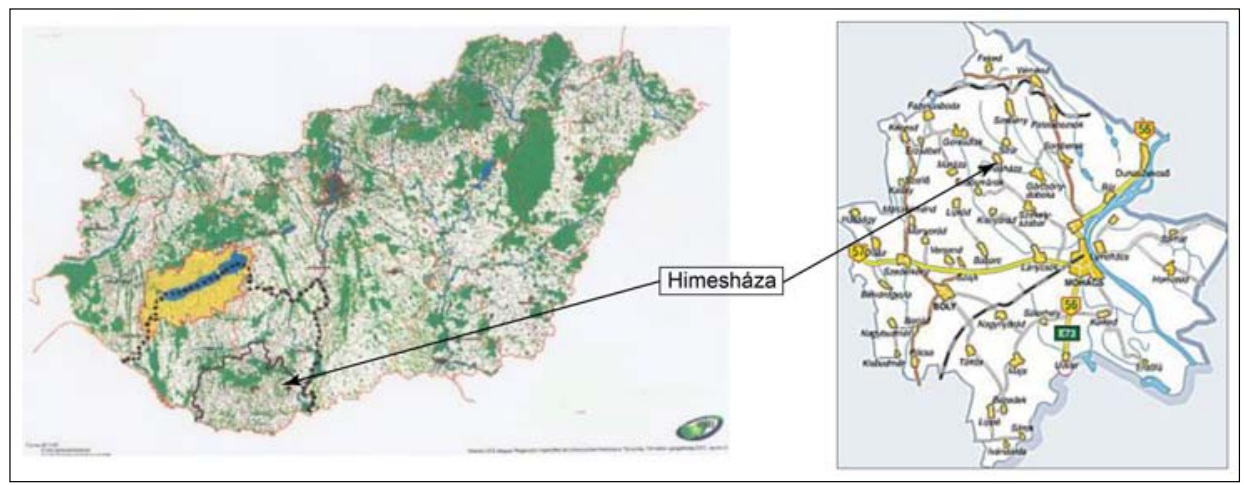

Fig. 5. Location of Himesháza in Hungary [6]

Fig. 6. Region of Mohács [7]; Source: dunaportal.hu 
The settlement is developing. It features a basic spatial arrangement plan [18] and a regulation plan [19] necessary for development; the settlement also has a detailed feasibility study of a thermal energy supply network and an energy supply development plan [10].

Those sections of the construction plan of the settlement that have been selected for modification are shown in the V1, V2 and V3 plans that were used in the development plans of the settlement in which:

- V1 contains the authorization plan for the water rights of the new and two preexisting thermal wells;

- V2 contains a new study landscape protection study and a proposal for a green area development plan [13], and recommendations for

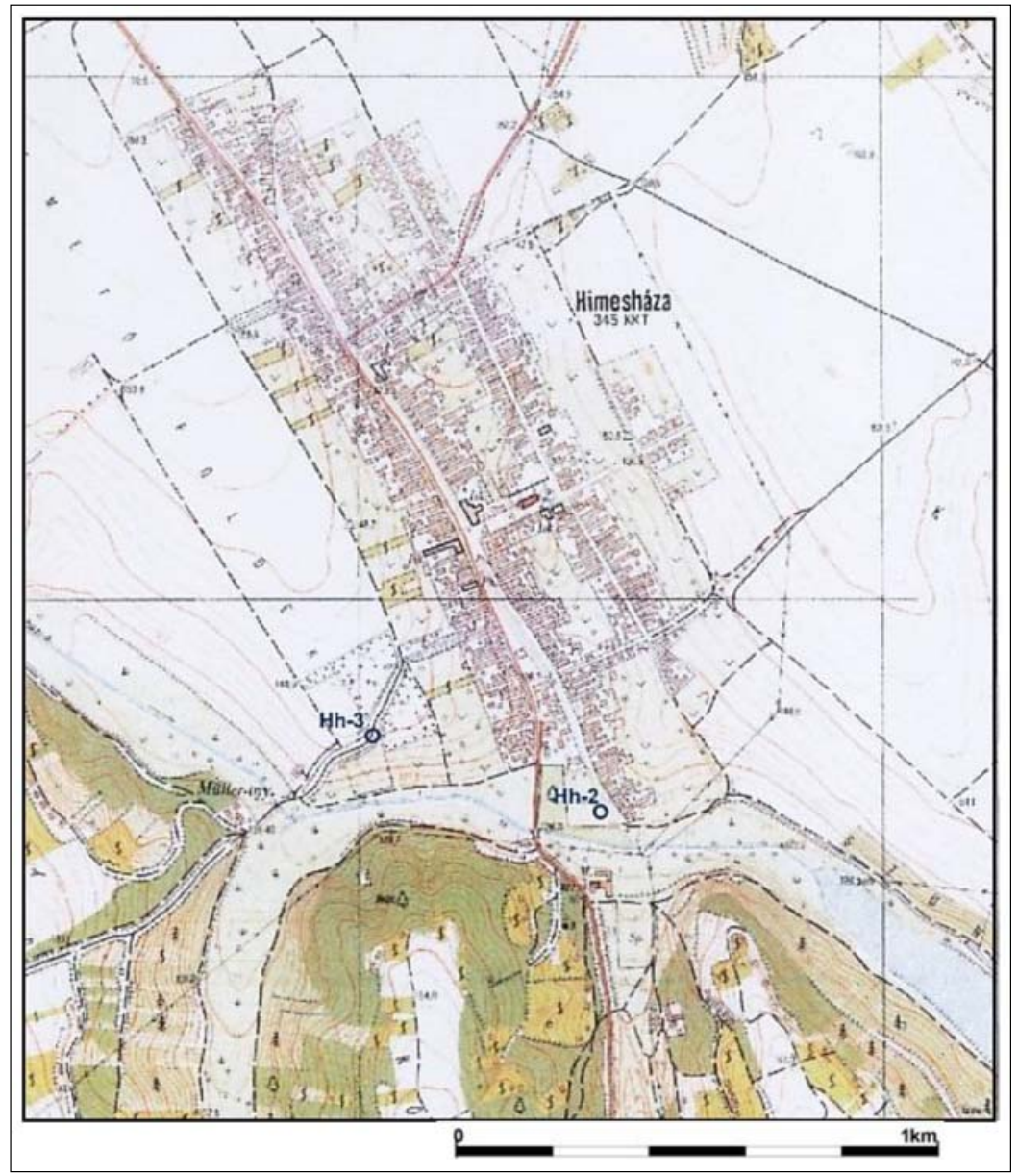

Fig. 7. Locations of wells Hh-2 and Hh-3 in Himesháza, according to the V2 Plansheet [10] 
a small-scale power plant that utilizes biogas as a complementary project;

- V3 contains recommendations for the landscape arrangement plan of the former fishing ponds and surrounding areas, and recommendations for utilizing the preexisting but closed thermal wells - among which the Well Hh-2 could act as a 'sink' (depending upon the results of drilling). In the case of unsatisfactory results for drilling regarding Well Hh-2, this well should act as the 'producing well' and Well Hh-3 could act as the 'sink' (Fig. 7).

Two deep wells are located in the southern part of Himesháza that produce thermal water, both from Upper Jurassic limestone. According to their registration numbers, these wells are 1$)$ no. $\mathrm{K}-6(\mathrm{Hh}-2)$ developed by a former mining company (Mecseki Ércbányászati Vállalat), and 2) no. K-7 (Hh-3) developed by the former water research company VIKUV (Table 1).

Table 1. Characteristics of the two thermal wells in Himesháza. Both wells are closed and out of service

\begin{tabular}{|l|c|c|}
\hline $\begin{array}{l}\text { Registration number } \\
\text { of thermal well }\end{array}$ & K-6 & K-7 \\
\hline Year of establishment & 1980 & 570 \\
\hline Absolute depth $(\mathrm{m})$ & 571 & $509.6-563.6$ (4 sieves) \\
\hline Depth of sieving $(\mathrm{m})$ & $486-571(3$ sieves $)$ & -46 \\
\hline Stratum sieved & upper Jurassic limestone & upper Jurassic limestone \\
\hline $\begin{array}{l}\text { Water level at steady state } \\
\text { (m below surface) }\end{array}$ & -33 & 48.6 \\
\hline Outflow water temp. $\left({ }^{\circ} \mathrm{C}\right)$ & 45.6 & \\
\hline
\end{tabular}

Details about the wells that are planned to be drilled are shown in Table 2 (coordinates of the National Projection System - EOV, and the special registration numbers of the local county).

Table 2. Landscape data on the planned thermal wells in Himesháza

\begin{tabular}{|l|c|c|c|l|}
\hline $\begin{array}{l}\text { Registration number } \\
\text { of wells }\end{array}$ & EOV Y & EOV X & Z & Parcel number \\
\hline Hh-2 & 613460 & 81595 & 125 & Himesháza 476/2 \\
\hline Hh-3 & 613025 & 81740 & 139 & Himesháza 8/3 \\
\hline
\end{tabular}




\subsection{Brief characterization of the ecological environment of the development plan}

No nature reserve, Natura 2000 area, or any type of protected landscape can be found on the administrative territory of Himesháza. The nearest one of these is an Illyrian oak-hornbeam forest (Erythronion-Carpinion) with nests of critically endangered white-tailed eagle (Haliaeetus albicilla) nested - a Natura 2000 area (code HUDD20067) located in Székelyszabar 2-2.5 km to the south. Creeks, water courses, and accompanying groves and grassy areas located in the region act as green corridors besides their landscape value. These areas are part of the National Ecological Network (Fig. 8) because of their potentials in protecting ecological values, connecting valuable habitats and maintaining undisturbed exchange of wildlife populations.

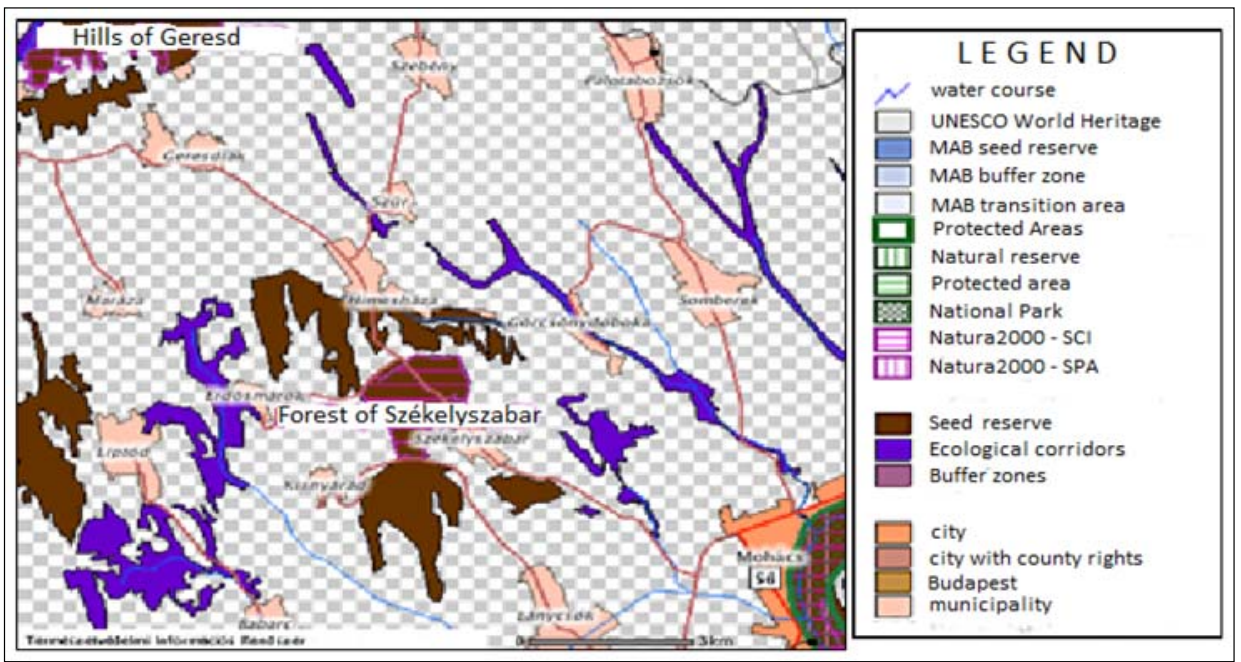

Fig. 8. The Illyrian oak-hornbeam forest near Székelyszabar that is part of the National Ecological Network and the Natura 2000 network [7, 12]

"Comparison of local potential of renewable energy resources with nationwide potential and the proposal for scaling-up utilization in the long term"

Comparison of local renewable energy capabilities with national potential and extend their utilization to a longer term.

\section{The potential of renewable energy resources}

\subsection{Geothermal energy utilization}

Hungary, together with the Carpathian Basin, has favorable heat flux values (Figure 9), with an average of $90-100 \mathrm{~mW} / \mathrm{m}^{2}$, which is double that of the con- 


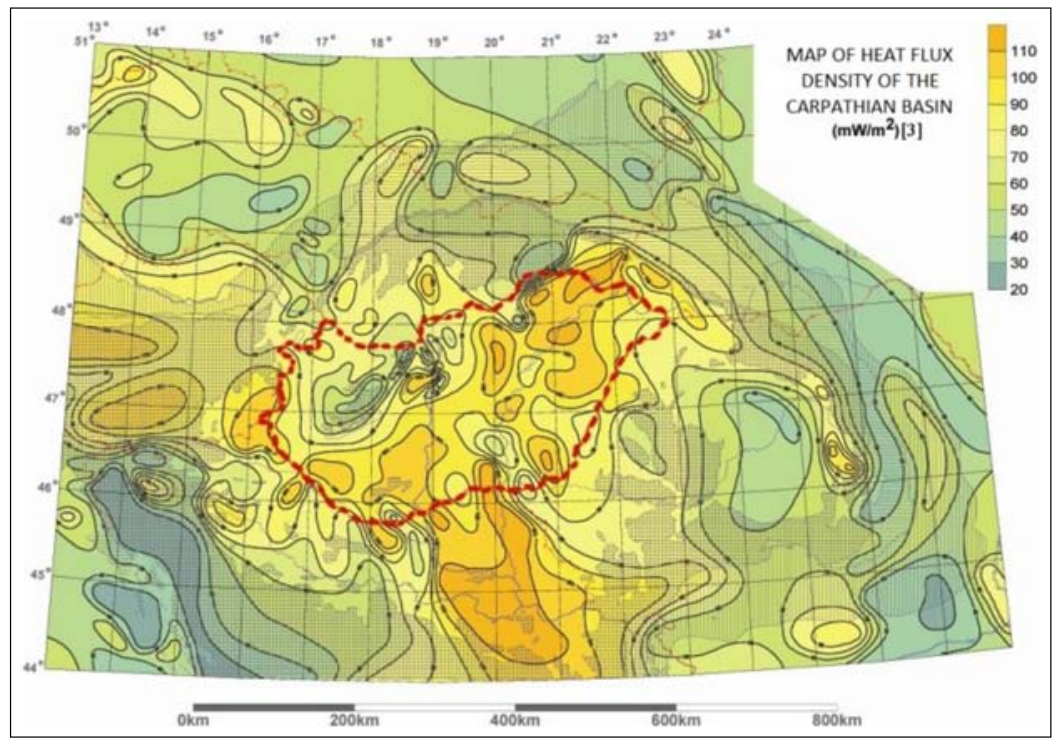

Fig. 9. Map of the heat flux density of the Carpathian Basin and surrounding region $[13,14,15]$

tinental average. The heat gradient (the rate of temperature change with respect to depth) is $0.042-0.066^{\circ} \mathrm{C} / \mathrm{m}$, meaning that the temperature at depths of 800-900 m can reach or exceed $60{ }^{\circ} \mathrm{C}$, and $90{ }^{\circ} \mathrm{C}$ at depths of $1,400-1,500$ $\mathrm{m}$. The latter is applicable not only for harvesting heat energy, but also for running geothermal power plant using the proper technology.

The majority of the country's territory has great potential for exploration and utilization according to the spatial distribution of thermal water (Figs 10, 11). Exploratory work and research dates back more than hundred years in Baranya county and the Mohács region. This may be useful for development and planning agencies and investors.

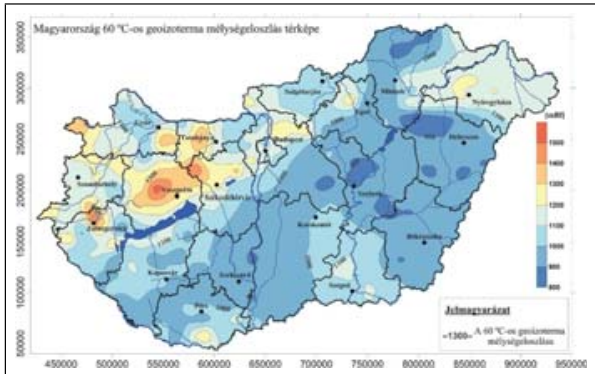

Fig. 10. Geo-isothermal map $\left(60^{\circ} \mathrm{C}\right)$ of Hungary [11]

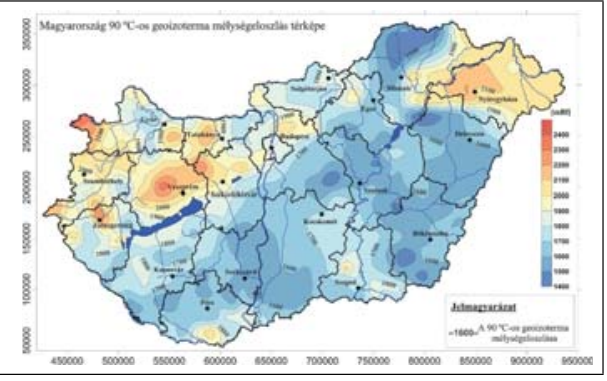

Fig. 11. Geo-isothermal map $\left(90^{\circ} \mathrm{C}\right)$ of Hungary [11] 
Among the thermal water aquifers, karstic ones containing water of a temperature of $>50{ }^{\circ} \mathrm{C}$ should be targeted, utilized, and injected back in the present case. Previous planning was also based on such considerations.

Based on the geothermal characteristics mentioned above, it would be reasonable for Baranya county to encourage not only the development of a district heating system to be installed in cities, but also the development of smaller-scale, decentralized heating systems for dynamic settlements. Furthermore, the relevance of multifunctional and combined geothermal energy systems (heating, bathing complexes, special heating systems for agricultural or livestock purposes, horticulture, fishing ponds, etc.) should also be emphasized.

Himesháza aims to develop a bathing complex for recreational purposes in the region of the mill that is to be reconstructed, according to medium-term plans.

Several settlements in close proximity to Himesháza have already explored thermal wells (Mohács, Szajk, Bóly, Somberek, and Töttös), according to the Hungarian Bureau of Energy and Utility-Regulations (MEKH) [11]. This national study shows the location and distribution of thermal wells with national registry numbers, on a county basis, and clusters them according to outflow temperature. The section of the study about Baranya county (see Fig. 12) shows not only the distribution of wells, but also the main character-

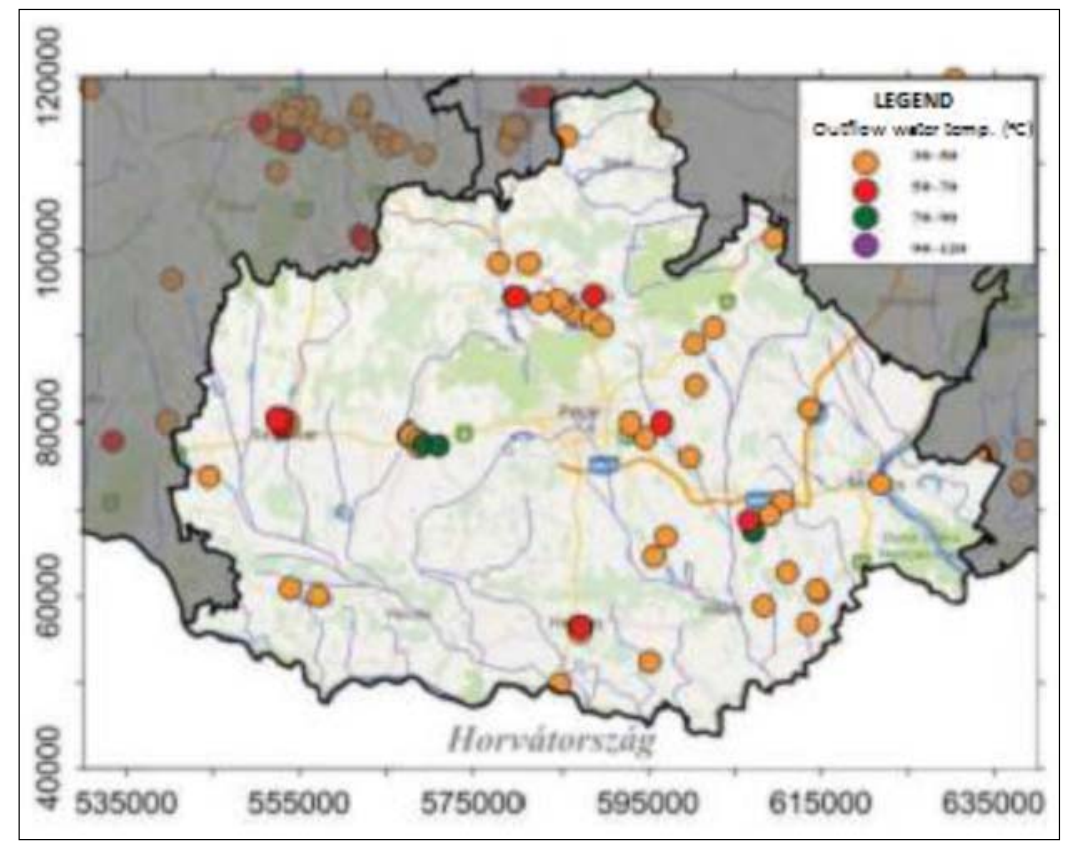

Fig. 12. Distribution of registered thermal wells in Baranya county [11] 
Table 3. Registered thermal wells in Baranya county [11]

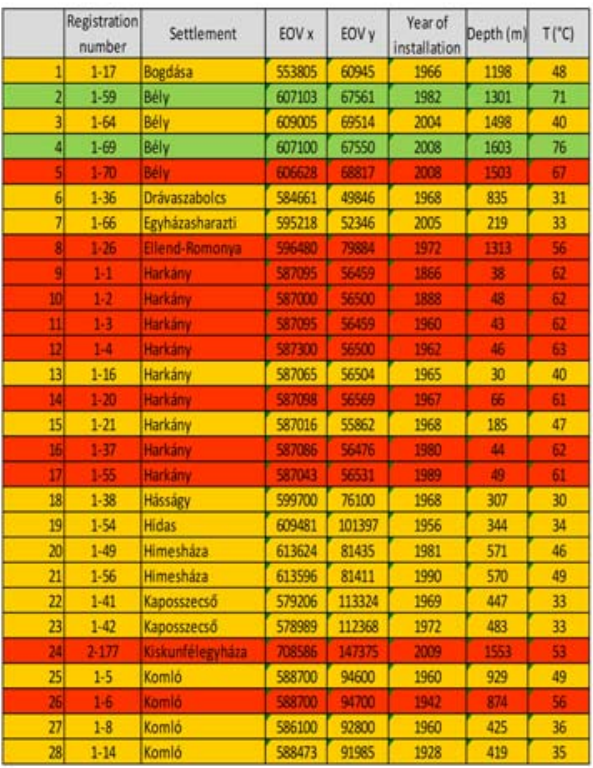

\begin{tabular}{|c|c|c|c|c|c|c|c|}
\hline 29 & 1.63 & Komlo & 589600 & 91000 & 1952 & 542 & 36 \\
\hline 30 & $1-39$ & Lippó & 613369 & 56841 & 1981 & 400 & 34 \\
\hline 31 & 1.22 & Majgocs & 585600 & 113100 & 1969 & 377 & 37 \\
\hline 32. & $1 \cdot 10$ & Magyarhertelend & 579747 & 94530 & 1958 & 400 & 43 \\
\hline 33 & $1-31$ & Maryarhertelend & 579848 & 94490 & 1979 & 1027 & 64 \\
\hline 34 & $1-61$ & Maryarhertelend & 582502 & 93729 & 2004 & 714 & 42 \\
\hline 35 & 1.57 & Magyarsarlós & 594708 & 78329 & 1993 & 453 & 34 \\
\hline 36 & 1.9 & Magyarszék & 585100 & 93400 & 1960 & 480 & 35 \\
\hline 37 & 1.24 & Magyarszék & 584578 & 94069 & 1971 & 392 & 38 \\
\hline 38 & $1-40$ & Mais & 614600 & 60400 & 1963 & 330 & 33 \\
\hline 39 & 1.72 & Majs & 614537 & 60819 & 2011 & 249 & 36 \\
\hline 40 & 1.51 & Mirok & 608259 & 58926 & 1983 & 278 & 33 \\
\hline 41 & 1.65 & Mohács & 621827 & 73035 & 2005 & 747 & 47 \\
\hline 42 & 1.62 & Nagykozár & 592895 & 79907 & 2003 & 726 & 46 \\
\hline 43 & $1-43$ & Oroszló & 577978 & 98448 & 1958 & 432 & 30 \\
\hline 44. & 1.7 & Pécsvánad & 600323 & 89024 & 1990 & 374 & 37 \\
\hline 45 & 1.52 & Pécsvárad & 602466 & 90834 & 1986 & 389 & 30 \\
\hline 46 & 1.71 & Pécsvárad & 601527 & 90515 & 2009 & 601 & 36 \\
\hline 47 & 1.19 & Pettend & 544533 & 73922 & 1966 & 2416 & 40 \\
\hline 48 & 1.60 & Sellye & 557122 & 60019 & 1999 & 712 & 46 \\
\hline 49 & 1.53 & Srajk & 610626 & 71093 & 1986 & 550 & 34 \\
\hline 50 & 1.11 & Szentlórinc & 567500 & 78800 & 1969 & 450 & 38 \\
\hline 51. & 1.15 & Szentlórinc & 568700 & 77400 & 1965 & 448 & 35 \\
\hline 52 & 1.44 & Szentlórinc & 567500 & 78700 & 1969 & 499 & 33 \\
\hline 53 & $1-45$ & Szentlórinc & 567707 & 78716 & 1979 & 538 & 33 \\
\hline 54 & $1-46$ & Szentlórinc & 568738 & 78297 & 1980 & 430 & 32 \\
\hline 55 & 1.67 & Szentlórinc & 569250 & 77690 & 2009 & 1821 & 85 \\
\hline 56 & 1.68 & Szentlórinc & 570052 & 77566 & 2010 & 1651 & 77 \\
\hline 57] & 1.18 & Ssigetvatr & 553000 & 79600 & 1966 & 792 & 62 \\
\hline 58 & 1.25 & Srigetvár & 553700 & 79900 & 1972 & 341 & 36 \\
\hline 59 & 1.29 & Szigetvir & 552975 & 79879 & $19 \pi$ & 781 & 62 \\
\hline 60 & $1=30$ & Srigetvir & 552871 & 80409 & 1979 & 997 & 60 \\
\hline 61 & 1.74 & Srigetvit & 552270 & 80449 & 2013 & 1029 & 58 \\
\hline 62. & 1.58 & Szilágy & 600395 & 84251 & 1993 & 396 & 41 \\
\hline 63 & 1.73 & Tottós & 611038 & 62912 & 2014 & 445 & 36 \\
\hline 64 & 1.23 & Û́petre & 597040 & 66898 & 1970 & 449 & 40 \\
\hline
\end{tabular}

istics of the 66 registered thermal wells (see Table 3). Consequently, there are two thermal wells in Himesháza, listed under numbers 20 and 21.

International proposals based on the temperature of geothermal energy resources have examined possible forms of utilization (using the Lindal Diagram), while another system assigns known power plant technologies to fluid temperatures (after Ungemach, P.). Based on these proposals, power generation with Binary ORC technology - a small scale, closed-loop system - can be used in the project region for thermal water with an outflow temperature of $90^{\circ} \mathrm{C}$ [16-21].

All means of energy transmission included in the Action Plan of Renewable Energy Utilization for Hungary (MMCST) fulfill the strategic principles and requirements of the EU that prioritize sustainability, security of supply, and competitiveness. This involves the implementation of the selected technologies for heat energy supply and utilization based on local geothermal energy resources that satisfy the priorities mentioned in the planning, organization, and preparation of the project work.

All local development projects based on renewable energy resources, including the undertakings involved in the current project, contribute to shifting the energy resource sector in a more modern, environmentally conscious 
direction. In order to support and enhance that shift, new energy consumers (institutions, and public and private facilities) could be connected to the network, and the utilization of geothermal energy potential (thermal water of $T$ $>50{ }^{\circ} \mathrm{C}$ ) could be maximized through a structured and cascading system of utilization.

\subsection{Solar energy utilization}

The volume of annual solar radiation that arrives to the Earth's surface is ca. $2 \times 10^{24} \mathrm{~J}$. The portion of this amount that reaches continental land is some 2000 times more than annual global energy consumption. Average total daily radiation in Hungary is ca. $3.15-3.65 \mathrm{kWh} / \mathrm{m}^{2}$, which means an annual 1,150-1,332 kWh/m² (Fig. 13).

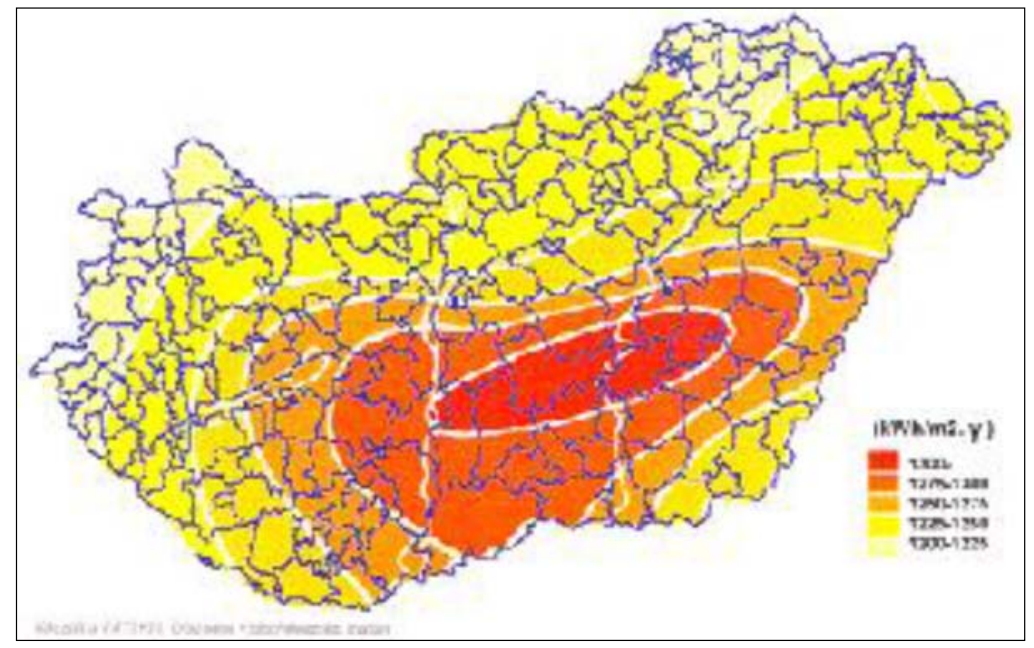

Fig. 13. Regional distribution of solar irradiation in Hungary [22, 23]

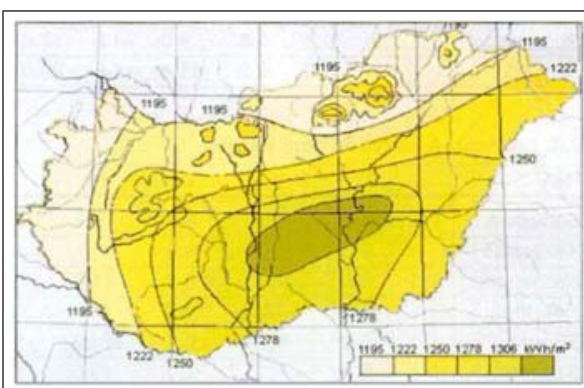

Fig. 14. Regional distribution of solar irradiation [22]

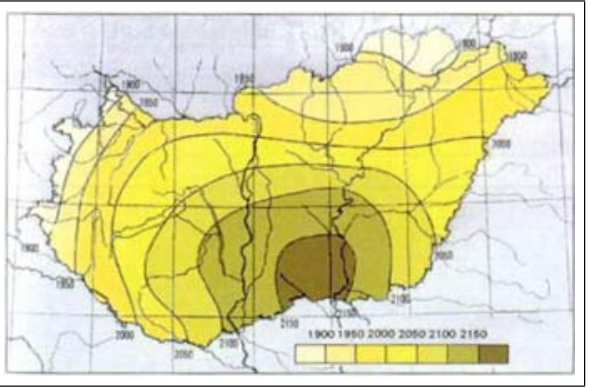

Fig. 15. Regional distribution of the hours of sunlight [22] 
The spatial distribution of irradiation and the hours of sunlight are variable in Hungary, resulting in 1,250-1,275 $\mathrm{kWh} / \mathrm{m}^{2}$ annual irradiation and more than 2,100 hours of sunlight per year at the project site. These factors are favorable, and make the area suitable for both direct heat energy conversion - heating, cooling, and domestic hot water production, and electricity production - photovoltaic (PV) technology (Figs 14, 15).

The area under analysis is also appropriate for harvesting passive solar energy because of its potential; moreover, energy savings can be achieved and consumption decreased.

The number of household-sized small power plants that utilize solar energy has rapidly increased in past years in Hungary, including in the region covered by the Eon-Déldunántúli Áramszolgáltató (the local energy supplier for the project region, southern Hungary), whose total capacity reached 20.78 MW in 2015, compared to $9.43 \mathrm{MW}$ in the previous year. However, if these small power plants based on renewable energy sources (geothermal, solar, wind, hydro, biomass, etc.) operated under a smart grid system this could generate multiple benefits increasing controllability and adjustability, instead of the current scheme of isolated production. The installment and utilization of small-medium capacity PV systems for households has already started in Himesháza [24-28]. The installation of larger PV systems with capacities of 50-100-1000 kW is also increasing in national energy supply centers and larger institutions, schools, universities, hospitals, etc.; their establishment and operation are supported at the governmental or self-governmental level. Baranya county is a highly supported region (in relation to western- and southern-Hungary) in this regard, where total solar energy production was ca. 2.5-16 MW in 2015.

\subsection{Wind energy utilization}

The magnitude and potential of wind energy depends on the constant movement of the atmosphere and its speed dependent energy density. Wind energy of 500000 TWh electrical energy equivalent is being produced in the atmosphere on a daily basis, of which $2 \%$ (10000 TWh) can be utilized via current technologies. Utilizable specific wind potential in Hungary is ca. $635-900 \mathrm{kWh} / \mathrm{m}^{2}$ per year, depending on geographical and climatic characteristics, wind speed, etc.

For wind energy utilization wind turbines require different wind speeds at different altitudes $(2.5-3 \mathrm{~m} / \mathrm{s}$ and $4.5-8.5 \mathrm{~m} / \mathrm{s})$, which values (magnitude, direction and distribution of wind) can be measured with increasingly modern technologies and greater accuracy.

According to research by the Hungarian Academy of Sciences, the theoretical wind energy potential of Hungary is ca. $36000 \mathrm{PJ} /$ year, of which the utilizable potential is ca. $532 \mathrm{PJ} /$ year. Taking into account protected ar- 
eas and zones, wind energy production is permitted on and suitable for a maximum of $7.8 \%$ of Hungary's territory. This means that a maximum of 60000-65000 MW declared capacity can be produced with wind turbines and the current technology in Hungary [29]. According to another assessment [30] the amount of potential wind energy in the country (at 75 meters) is ca. $204 \mathrm{PJ} /$ year, which represents 6,489 MW capacity. In 2010 only 155 wind turbines were in operation, delivering $295 \mathrm{MW}$ total capacity, with another 34 MW under development. The value of the intended investment exceeds this amount by many times; in 2010 additional developments of 410 MW capacity were shut down and the related tenders were revoked. On the other hand, the installation of low-capacity wind turbines (1.5-3 MW) can be carried out without difficulty [31].

The installation and support of household-scale wind turbines that require no license appears to be possible with no obstacles at the governance level. The number and installed capacity of such turbines is increasing according to national statistics. Proper environmental (impact) assessments and proposals have been carried out within the frames of the current project about the installation of conventional wind turbines with higher capacity to ensure compliance with national and international regulations and principles.

The previous claim is more valid in the case of Mohács region and Himesháza specifically, where the protection of the aforementioned values takes priority [12], while the region is specific in terms of renewable energy utilization.

\subsection{Hydropower utilization}

Hydro power is the most utilized renewable energy resource globally (highly relevant in 150 countries). In Europe, Norway covers 100\% of its electricity consumption with hydropower generation, while the proportion in Sweden, Austria, Switzerland and Italy is ca. $60-70 \%$; the utilization of this energy is relatively high in Europe, with an average contribution to electricity consumption of $15 \%$.

The theoretical hydropower potential of Hungarian rivers is $10 \mathrm{TWh} /$ year, of which $50 \%$ involves so-called permanent water flow with a theoretical electrical energy volume of ca. 7.4 TWh/year and ca. $900 \mathrm{MW}$ capacity. The currently utilized volume in Hungary is less than $210 \mathrm{GWh}$ /year - meaning that 36 times more power could be utilized by the potential hydropower plants marked on the map (Fig. 16) [32]. Medium-capacity hydropower plants currently operating in Hungary have a total capacity of 48.8 MW, which, together with the low-capacity plants installed on smaller rivers and creeks, amounts to $3.2 \mathrm{MW}$; slightly more than $50 \mathrm{MW} /$ year utilized capacity. However, an exploration of the Hungarian hydro potential indicates 


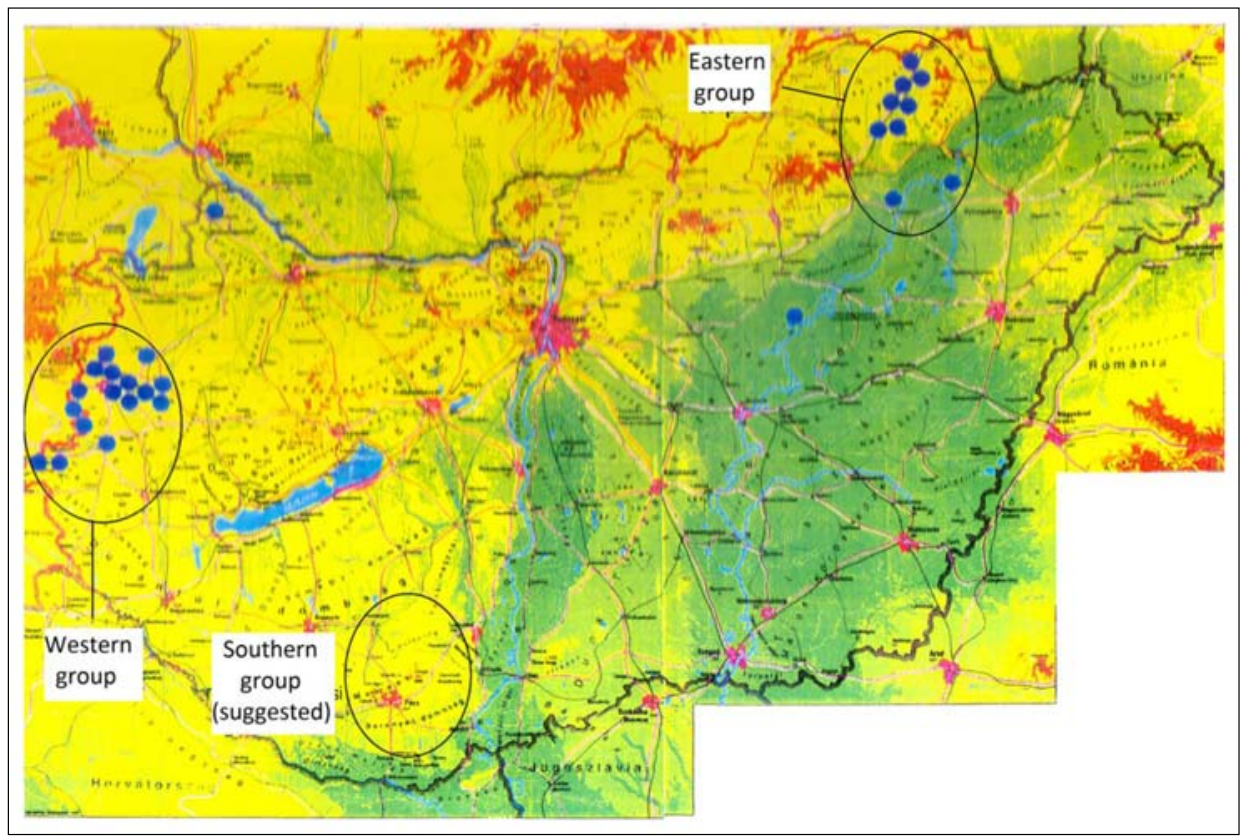

Fig. 16. Locations of the low-capacity hydropower plants in Hungary [32-34]

that the estimated capacity of the Danube, the Tisza, and the Dráva are ca. 970, 135 and 109, MW respectively, according to studies by the Hungarian Academy of Science, giving a total of $1214 \mathrm{MW}$.

The 50 MW capacity hydropower plant formerly planned together with the dam at Mohács will not be relevant until ca. 2030 at least, unless it is brought forward for certain reasons. Hungarian energy politics do not particularly support hydropower utilization, in contrast to European and global practice. It can be said that only low-capacity plants with a capacity of less than $1 \mathrm{MW}$ are thus privileged.

These low-capacity plants typically utilize hydropower close to the eastern and western borders - 16 in the western ("Western group") and 10 in the eastern border region ("Eastern group") (Fig. 16). This form of technology could be used in other regions of the country with similar hydrological characteristics [33].

One of the conceptual proposals of this study is, after conducting proper exploratory research, to install such low-capacity hydropower plants ("Southern group") in the region of Himesháza. The plants should be installed on the water courses delineated by the study [30].

Looking at the economic advantages, these low-capacity plants with different outputs could discharge into the local low- and medium-voltage (0.4 and $20 \mathrm{kV}$ ) electrical network. These networks operate properly and could be 
improved in such a way as to become part of a 'smart grid' system, as mentioned before, based on the local technology of such low-capacity plants [31].

\subsection{Biomass energy utilization}

Biomass refers to biological materials that can be used as an energy resource; the former is a renewable energy carrier material created by solar energy conversion. Because of its heterogeneity, multiple technologies are known for its utilization. These are structured and grouped according to the type of biomass in Fig. 17.

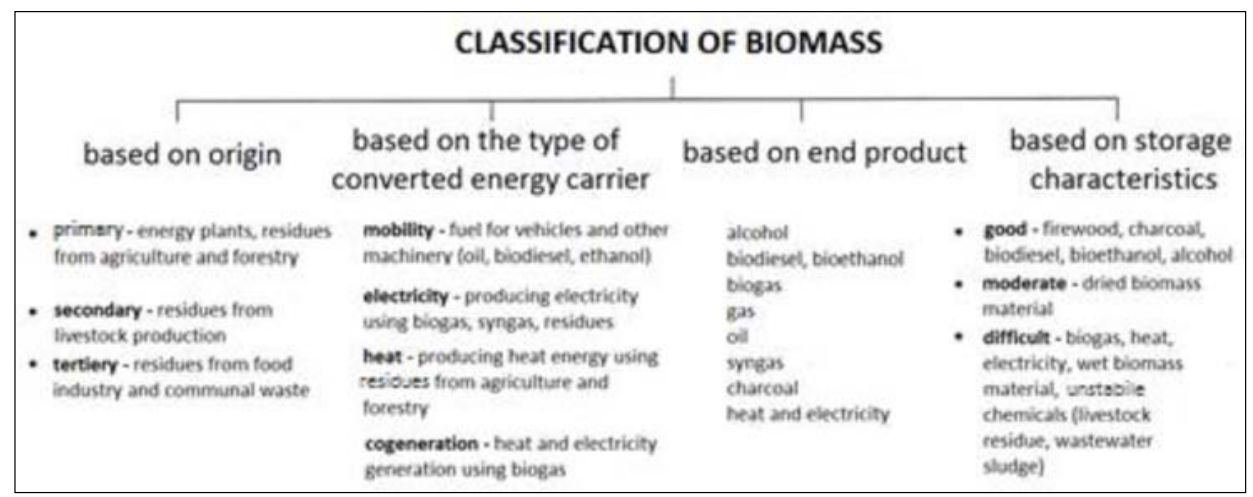

Fig. 17. Classification of biomass [35]

Among the energy utilization and conversion technologies for biomass, traditional thermochemical conversion (burning) has been the most preferred. The burning of wood and forestry leftovers together with coal was used to produce heat energy, while later these materials were converted in power plants to generate combined electrical and heat energy. These technologies are now considered out-of-date, polluting, and inefficient. New approaches aim to produce biogas via gasification, pyrolysis, or anaerobic digestion. Similar products such as biogas, biodiesel, and bioethanol can also be produced via biochemical processes, fermentation, and pressing.

Hungary has a biomass potential that is higher than the European average because of its favorable agricultural characteristics. According to one of the valid estimations carried out by the Hungarian Academy of Sciences, the national potential for conversion is ca. 203-328 PJ/year; this is the value used in long-term strategies [36].

The spatial distribution of this potential is not homogeneous because the regions and counties of Hungary are different not only in terms of the territorial patterns of forestry, but also in the energy potential of materi- 


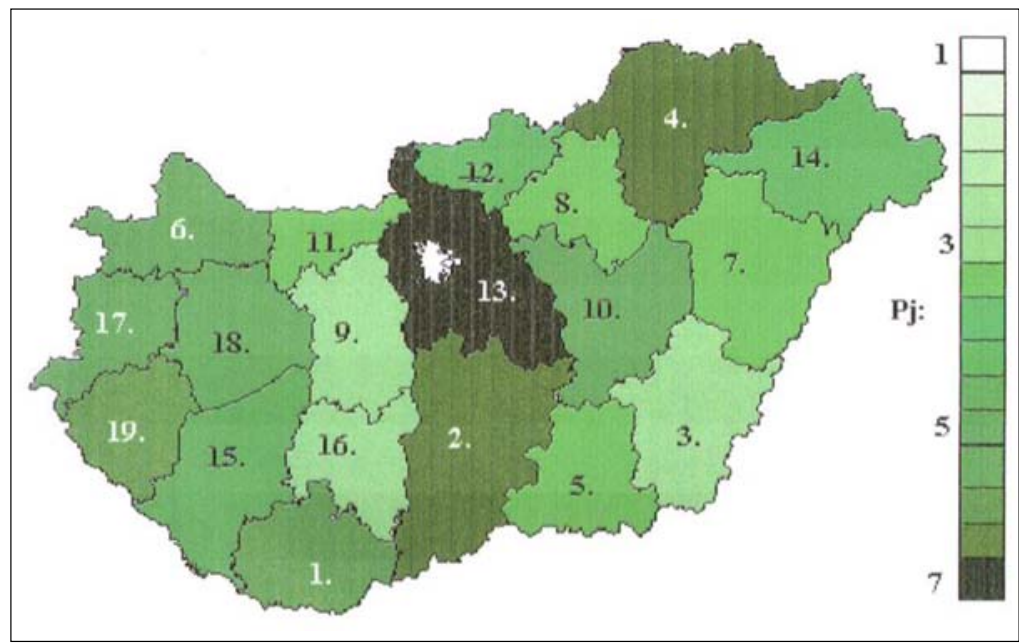

Fig. 18. Energy content of total biomass in the counties of Hungary [35]

als and residuals from forestry and agricultural production. The territorial structure of biomass potential is shown in Fig. 18. It is visible that Pest county has the greatest potential at more than $7 \mathrm{PJ} /$ year because of its significant amount of forests. Baranya county has a rather average value; $4.8-5$ $\mathrm{PJ} /$ year.

Among the technologies described above for biomass utilization, biogas production seems to be the most suitable and can be recommended for even mid-term planning in the region of Himesháza. This could be developed in connection with a local pig farm to utilize organic waste by installing appropriate biogas-producing technology. The technology would be suitable for accepting waste materials from the region as well. This proposal, now at the stage of conception, needs thorough exploratory work in order to better inform decision makers. According to national studies, the utilization of organic waste from agricultural and farming sectors is highly recommended in Baranya county $[35,37]$.

From a survey of Hungary's biogas potential, it was concluded that $222.84 \mathrm{PJ} /$ year can be utilized, which is 4,708 million $\mathrm{m}^{3}$ in terms of natural gas equivalent. This amount would be sufficient to supply $60 \%$ of the consumers of the natural gas network of Hungary. When following the legal instructions and standards of the gas network, biogas that is produced can be discharged into the network.

The region's long-term (2030) and longer-term (2050) plans can effectively affect the sustainability of local developments and their coordinated extension with climate change in accordance with domestic assistance intentions. 


\section{Long-term scenarios (2030)}

In order to carry out a well-established and sustainable heat energy supply project at the settlement level at Himesháza based on geothermal energy potential, it is reasonable to consider and examine, after complex and regional exploratory work and energy potential evaluations, whether the project will be viable and economic in the future, and if the conditions for potential further development will be ensured (i.e. political or economic support).

The future perspectives of the region and the settlement can be based on national and regional development plans carried out with traditional planning methods. The most relevant of these for setting future direction is the National Development 2030 - Concept of Regional Development in Hungary document (Nemzeti Fejlesztés 2030 - Országos Területfejlesztési Koncepció, OFTK), adopted in 2014 by the Hungarian Parliament. The novelty of this document is that it is based on political strategy but is professionally well-founded, as all industrial branches and county-level-governing bodies took part in its development. Further, the document defines guidelines in an integrated way and indicates a paradigm shift towards, for instance, the independence of Hungary's energy supply. The combined development of

Table 4. National Priorities and Development Areas according to the OFTK [2]

\begin{tabular}{|l|l|l|}
\hline \multicolumn{1}{|c|}{ National priorities } & \multicolumn{1}{c|}{ Development areas } \\
\hline 1. & $\begin{array}{l}\text { Patriotic economy based on small } \\
\text { and medium-sized enterprises, } \\
\text { and in partnership with large- } \\
\text { sized enterprises }\end{array}$ & $\begin{array}{l}\text { - Innovative economic development; com- } \\
\text { petitiveness of small- and medium sized } \\
\text { enterprises, and strategic sectors } \\
\text { - Renewable public transportation } \\
\text { - Resilient rural areas, developing agro- } \\
\text { and food industry, fisheries }\end{array}$ \\
\hline 2. & $\begin{array}{l}\text { Aiming for full employment and } \\
\text { knowledge-based society }\end{array}$ & $\begin{array}{l}\text { - Increasing employment } \\
\text { - Establishing a knowledge-based society }\end{array}$ \\
\hline 3. & $\begin{array}{l}\text { Approaching resource and energy } \\
\text { efficiency, and energy independ- } \\
\text { ence }\end{array}$ & $\begin{array}{l}\text { - Energy efficiency and sustainable re- } \\
\text { source management } \\
\text { - Climate and environmental protection }\end{array}$ \\
\hline 4. & $\begin{array}{l}\text { Growing population and develop- } \\
\text { ing communities }\end{array}$ & $\begin{array}{l}\text { - An open and growing society } \\
\text { - Stimulating childbearing and addressing } \\
\text { demographic issues }\end{array}$ \\
\hline 5. & $\begin{array}{l}\text { Integration and development on } \\
\text { regional and economic level }\end{array}$ & $\begin{array}{l}\text { - Regional development and integration } \\
\text { - Economy and communities of rural areas } \\
\text { - Budapest and its region in a leading role } \\
\text { - Flourishing cooperation within the } \\
\text { Carpathian Basin, along the Danube and } \\
\text { throughout Europe }\end{array}$ \\
\hline
\end{tabular}


the local and regional economy is emphasized in the paper, which bases the evaluation of the settlement network on an economic perspective. The objectives of OFTK are based on the Development Areas of the medium-term (2014-2020) National Priorities, which developments are planned to be implemented by 2020. The priorities of the Himesháza project relate to Priorities and Development Areas numbers 3 and 5 in Table 4.

The perspective of the Himesháza project is for the region to 1) reach its specific goals regarding policy through support connected to the relevant priorities, 2) be connected to the achievement of the specific goals of the region, thereby contributing to Hungary's future role by 2030; and becoming one of the economic and intellectual centers of Central-Eastern Europe. This visionary conception aims to fulfill the following goals by 2030:

- create an engaging economic atmosphere

- foster population growth and community development

- strategically utilize natural resources

- support the existence of a balanced landscape

\subsection{Long-term trends in relation to renewable energy utilization}

Building on the explored potentials for local renewable energy resources, the rapidly increasing need for such resources can start to be satisfied even in the medium-term in Hungary. This can be followed by the development and expansion of utilization technologies, and an increase in their share among the total energy utilization. Scenarios for the longer term based on official studies cannot be guaranteed sufficient certainty, because the actualization and correction of the MMCST is still ongoing. The former prognosis for Hungary in terms of the proportion of renewables among electricity production envisions a share of merely $35 \%$ by 2050 . However the prognosis in the case of electricity and heat energy production in the residential and public sector anticipates a $100 \%$ share of renewables.

\subsection{A proposal for the expansion of technologies for geothermal energy conversion}

The project can be carried out with sufficient certainty because of the energetic analyses that have been done for the smaller and broader region of Himesháza and its favorable potential. It can be assumed that the new thermal well, or one of the already available ones, with the proper deepening would be able to supply new consumers of heat energy (from the public-, business-, agricultural-, tourism sector, etc.) through an expanded centralized and a decentralized district heating network because of its favorable characteristics (the temperature and composition of the fluid and yield). 
Similarly, depending on the drilling and deepening results of the wells, the heating system may be able to fulfill the needs of recreational, vacation-based or complex thermal spa facilities formerly planned in the region. Moreover, the system could also be capable of utilizing a larger spectrum of renewable energy through its combination with PV (photovoltaic) technology, and feeding back and distributing the heat energy from the electrical energy that is produced into the low-, and medium-voltage electrical distribution network. This vision can be realized in the mid-term.

Technologies applicable to geothermal power plant setup in the future can be assessed based on a former exploratory study that mapped fault lines and reservoirs of carbonaceous thermal water in Hungary [1]. Among a wide range of technologies for on-site geothermal electric energy generation at a power plant [38], developments in ORC technology (a dual-fluid cycle system), namely Kalina-system technology, can be recommended for fluids with temperature range of $95^{\circ} \mathrm{C}-150^{\circ} \mathrm{C}$. In this case, the transfer medium during the second cycle is different from that used in the conventional ORC systems and increases efficiency. This form of technology is appropriate for such a project in the region, in the case that the well is drilled $2-2.2 \mathrm{~km}$ deep.

\section{Visions for the longer term (2050)}

It can be claimed that the high temperature thermal fluids of the region under exploration (Fig. 19) will be able to operate high-performance EGS- and

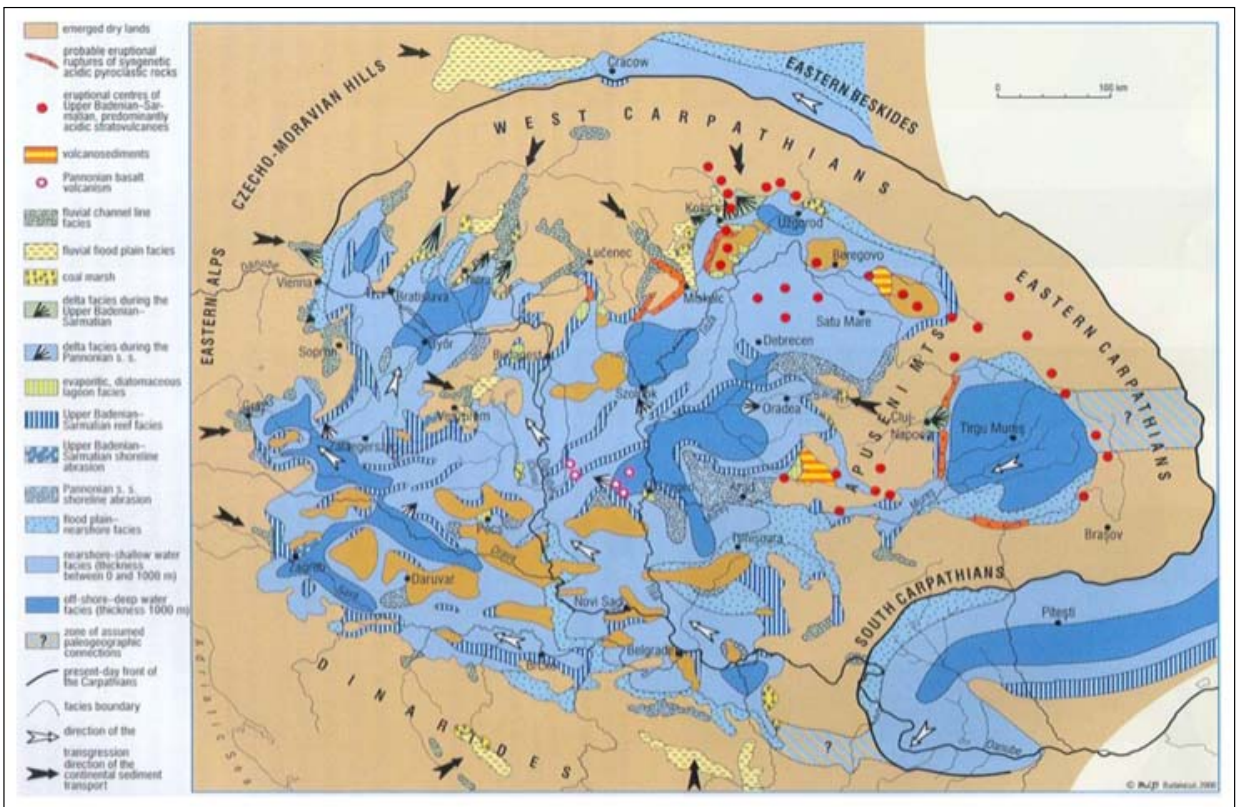

Fig. 19. Geological map about the Late-Miocene term of the Carpathian Basin (Hámor, 1999) [39, 40] 
HDR-type geothermal power plants. This could result in the power generation and cogeneration of electricity and heat, related marketing, and a decrease in GHG emissions.

As a prognosis for the longer term, the implementation of new technologies for renewable energy production is more probable regarding those technologies that are already known in Hungary because of their potential for utilization, and also those still in the pilot phase; these technologies are yet to become marketable (because of their high price), but are of higher efficiency and emit less pollution than current technologies and will meet the increasingly strict environmental standards of the future.

The completed National Strategic Environmental Assessment (SKV), part of the previously mentioned OFTK, identified the areas most vulnerable to climate change effects in the country and elaborated on the support needed in those regions. A map that summarizes the results of the assessment (Fig. 20) shows more than half of the country's territory as vulnerable. Several parts of Baranya county were classified as "among the most vulnerable" partly due to the effects of drought, increased summer temperatures and flooding events. This signals that the region will also receive similar governmental support in the future, along with support from the social sector.

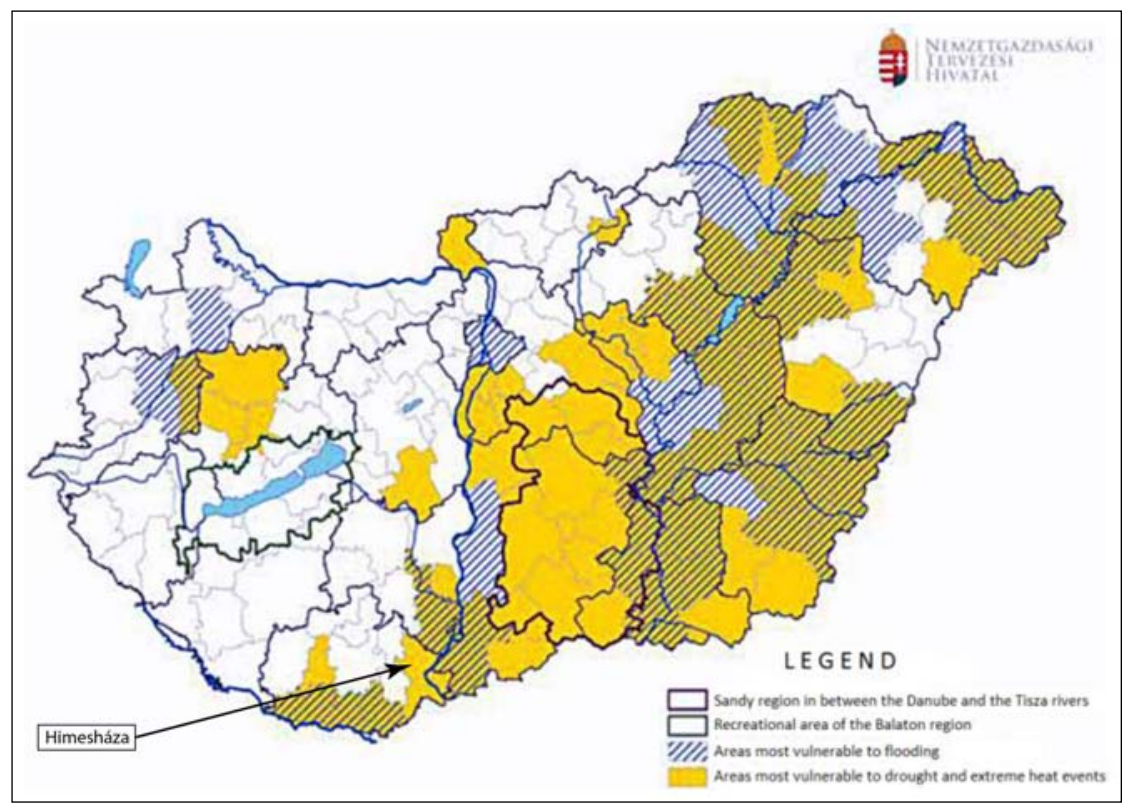

Fig. 20. Vulnerable areas of Hungary regarding climate change effects [2] 


\section{Conclusion}

The future perspectives of the region and the settlement are given by development plans, based on the document "National Development 2030 - Concept of Regional Development in Hungary", adopted in 2014. The document indicates a paradigm shift towards, for instance, the independence of Hungary's energy supply. The combined development of the local and regional economy is emphasized.

Building on the explored potentials for local renewable energy resources, the rapidly increasing need for such resources can start to be satisfied even in the medium-term in Hungary. This can be followed by the development and expansion of utilization technologies, and an increase in their share among the total energy utilization.

The actualization and correction of the Action Plan of Renewable Energy Utilization for Hungary is still ongoing, but the former prognosis for Hungary envisions a share of merely $35 \%$ by 2050 in terms of the proportion of renewables among electricity production; however, the prognosis in the case of electricity and heat energy production in the residential and public sector anticipates a $100 \%$ share of renewables.

In order to carry out a well-established and sustainable heat energy supply project at the settlement level at Himesháza based on geothermal energy potential, it is necessary to consider and examine the viability of the project. The project can be carried out with sufficient certainty. It would be able to supply new consumers of heat energy through an expanded centralized and a decentralized district heating network. The heating system may also be able to fulfill the needs of recreational, vacation-based or complex thermal spa facilities formerly planned in the region. Moreover, the system could also be capable of utilizing a larger spectrum of renewable energy through its combination with photovoltaic technology. This vision can be realized in the mid-term.

The high temperature thermal fluids of the region under exploration will be able to operate high-performance EGS- and HDR-type geothermal power plants. This could result in the power generation and cogeneration of electricity and heat and a decrease in GHG emissions.

As a prognosis for the longer term, the implementation of new technologies for renewable energy production is more probable; these are of higher efficiency and less polluting

\section{Legal sources}

[1*] 2003. évi XXVI. törvény az Országos Területrendezési Tervről [English: Hungary's Act XXVI of 2003 on the National Spatial Plan] 
[2*] A Természet védelméról szóló 1996. évi LIII. törvény 6.§ (3)-(4) és (5) bekezdés [English: Article 6, sections 3, 4 and 5 of Hungary's Act LIII of 1996 on nature conservation]

[3*] A Természet védelméról szóló 1996. évi LIII. törvény 53.§ az Országos Területrendezési Tervról (English: Act LIII of 1996 on nature conservation, Article 53 on the National Spatial Plan]

[4*] A 2015. évi LVII. Törvény az energiahatékonyságról [English: Hungary's Act LVII of 2015 on Energy Efficiency]

[5*] A 2009/28/EK az Európai Parlament és a Tanács irányelve (2009. ápr. 23.) a megújuló energiaforrásból elóállított energia támogatásáról, valamint a 2001/77/ EK és a 2003/30/EK irányelv módosításáról és azt követő hatályon kívül helyezéséról [English: Directive 2009/28/EC on the promotion of the use of energy from renewable sources, etc.]

[6*] Az EU 2017/2195 Rendelete (2017.11.23.) a villamos energia kiegyenlítő szabályozására vonatkozó iránymutatás. [English: EU Regulation 2017/2195 on establishing a guideline on electricity balancing]

[7*] A 299/2017. (X.17.) Korm. Rendelet (a megújuló energiaforrásból termelt villamos energia kötelező átvétele és prémium típusú támogatásáról) [English: Government Decree 299 of 2017 on the support and feed-in tariffs of electricity produced from renewable resources]

[8*] A 2019/2008 (II.23.) Kormányhatározat az Energiahatékonysági Cselekvési Tervról [English: Government Decision 2019 of 2008 on the Energy Efficiency Action Plan]

\section{References}

[1] Unk J. „Regionális megújuló energiagazdálkodás és energiaellátás kutatások, területi-fejlesztés koncepció és programjavaslatok, ezen belül a geotermikus energiahasznosítások" Önálló, folyamatos kutatás. Bp. VÁTI - PYLON 1981-2019. [English: Regional research on energy supply, concepts and recommendations of regional development, focusing on geothermal energy - ongoing research at VÁTI-PYLON Co.]

[2] Nemzeti Fejlesztés 2030 - Országos Területfejlesztési Koncepció OFTK 2013 [English: National Development 2030 - Concept of Regional Development in Hungary - OFKT 2013]

[3] Baranya Megye Integrált Területi Programja, 2017, Pécs. [English: Integrated Regional Program for Baranya county, 2017]

[4] Baranya Megyei Területfejlesztési Koncepció, 2014, Pécs. [English: Concept of Regional Development for Baranya county, 2014]

[5] BMGE Gazd. és Társad. Tud. Kar Szociológiai és Kommunikációs Tsz., Település és Területfejl. szakokt.: Múszaki Infrastruktúra tantárgy, Unk Jánosné: Területi energiagazdálkodás és ellátás, megújuló energiahasznosítás c. előadások 2004. [English: Unk J. 2004. Regional energy supply and management; renewable energy utilization - lecture]

[6] Himesháza község TeIR [English: Location of Himesháza]

[7] Himesháza a Mohácsi járásban TeIR [English: Location of Himesháza in the Mohács region]

[8] Himesháza Településrendezési Terve [English: Local Development Plan of Himesháza] 
[9] Böszörményi K. 2016. Tájvédelmi szakvélemény; Himesháza. Településrendezési eszközök módosítása. [English: Böszörményi K. 2016. Scientific Advice for Landscape Protection]

[10] Mecsekérc Zrt.: Himesháza Belterületén létesítendő termelő és visszasajtoló termálkútpár. Vízügyi létesítési engedély. [English: Permit for establishment of thermal wells in Himesháza]

[11] Tóth A. (MEKH): Magyarország Geotermikus Felmérése, 2016. MEKH kiadvány [English: Tóth A. 2016. Scientific Report on the geothermal potential in Hungary]

[12] Zsák F. Megalapozó kutatás; Megújuló energiahasznosítási rendszerek fejlesztési technológiáira, hazai, külföldi példák. [English: Primary research of technologies for renewable energy utilization]

[13] Haas J. 2001. Geology of Hungary. Eötvös University Press

[14] Árpási M. Szakvélemény a geotermikus energia hasznosításáról és a környezetvédelemmel való kapcsolódásáról Magyarországon. Budapest. 2006. dec. [English: Árpási M. 2006. Expert's Report on the utilization of geothermal energy and its connection to environmental protection in Hungary]

[15] Török J. A Kárpát-medence geológiai adottságai. In: Kisteleki Geotermikus Konferencia 2007. február 6-7. [English: Török J. 2007. Geological characteristics of the Carpathian Basin - Conference in Kistelek]

[16] BMKE Épületgépészeti tanszék: A Geotermikus energia és hasznosítása - tankönyv kézirata: 13. fejezet Unk Jánosné: Geotermikus villamos erómúvek, kapcsolt hőenergia átalakító és fútőmú rendszerek" 2016. április [Unk J. 2016. Geothermal power plants, co-generation of heat and electricity - book chapter from: Geothermal energy and utilization]

[17] Bobok E, Tóth A. Megújuló energiák. Miskolci Egyetemi Kiadó 2005. [English: Bobok E., Tóth A. 2005. Renewable energy. Miskolci Egyetem Kiadó]

[18] Dr. Unk Jánosné és munkacsoportja (PYLON Kft.) - Nyugat-Dunántúli Regionális Fejlesztési Tanács: Zalai geotermikus energiahasznosítás területfejlesztési Programja. Geotermikus Mintaerőmú A Nyugat-Dunántúli Régióban. Budapest. 2000. jún. [English: Unk J. and working group, Regional Development Council of Western Transdanubia. 2000. Regional development program through geothermal energy utilization in Zala county]

[19] PROTACON Kft., Unk Jánosné (PYLON Kft.). Balotaszállás-Mélykút térségi $\mathrm{CH}$-meddő fúrásból átképzett M3 és M6 jelú víztermelő és M7 jelú víznyelő kutakra, szúkebb területükre vonatkozó értékelési, hasznosítási terv előtanulmánya 2007ben. [English: Unk J., PROTACON Ltd. 2007. Valuation and plan of utilization of thermal wells M3, M6, M7 in the region of Balatonszállás-Mélykút]

[20] Nádasi Tamás, Udud Péter (AQUAPROFIT Rt.), Unk Jánosné (PYLON Kft.). Zala megye meddő szénhidrogén $\mathrm{CH}$ kutak hasznosítását feltáró és biztosító Előzetes Megvalósíthatósági Tanulmány I-II. rész. Területi-, hasznosítási-, múszaki-gazdaság és értékelési munkarészek. Budapest. 2002. július [English: Nádasi T., Udud P., Unk J. 2002. Exploration of utilization potential for unproductive hydrocarbon wells - Primary Feasibility Study]

[21] Árpási M., Unk J. A nagy gáztartalmú, 100 C-nál nagyobb felszíni hőmérsékletú geotermikus fluidum kombinált energiahasznosítási javaslata. In: Európai Geotermális Konferencia - Szeged, 2003. május 25-30. [English: Árpási M, Unk J. 2003. Pro- 
posal for various utilization of geothermal fluids with high gas content and temperature $\left(>100^{\circ} \mathrm{C}\right)$ - Conference Paper]

[22] PYLON Kft.: GKM V.1. sz. kutatási témája: A megújuló energiahordozó-felhasználás növelésének költségei c. kutatáshoz önálló háttértanulmányok. Pálfy Miklós: A napenergia aktív fotovillamos energiára történő hasznosítása. Kézirat. Budapest. 2004 (English: Pálfy M. 2004. Converting solar energy to electricity. Primary Study to "Costs of increasing the utilization of renewable energy resources")

[23] PYLON Kft.: GKM V.1. sz. kutatási témája: A megújuló energiahordozó-felhasználás növelésének költségei c. kutatáshoz önálló háttértanulmányok. Kaboldy Eszter: Napenergia aktív hőhasznosítás-módja napkollektorral kézirata, Budapest. 2004 [English: Kaboldy E. 2004. Means of utilization of solar energy via solar collectors. Primary Study to "Costs of increasing the utilization of renewable energy resources"]

[24] Farkas I., Kocsis L., Seres I. 2007. 10 kWp teljesítményú hálózatra kapcsolt fotovillamos rendszer első éves múködési tapasztalatai. [English: Experiences from the first year of utilizing photovoltaic system connected to an electrical network with $10 \mathrm{kWp}$ performance] MTA Agrármúszaki Bizottság Kutatási és Fejlesztési Tanácskozás Nr. 31, 3. k. 99-103

[25] MTA Energetikai Bizottság. Megújuló Energetikai Technológiák Albizottsága: A hazai megújuló energetikai potenciál reális értékeinek közelítő meghatározása 2003. [English: Hungarian Academy of Sciences. 2003. Approximation of the realistic value of the Hungarian renewable energy potential]

[26] MTA Köztestületi Stratégiai Programok: Megújuló Energiák Hasznosítása 2010 [English: Hungarian Academy of Sciences - Strategic Programs. 2010. Utilization of renewable energy]

[27] MTA Energetikai Bizottsága, Megújuló Energia Albizottsága: Farkas István, Kapros Zoltán, Unk Jánosné: A napenergia hasznosításának hazai lehetőségei. Budapest. 2009. febr. [English: Farkas I., Kapros Z., Unk J. 2009. Potential of solar energy utilization in Hungary. Hungarian Academy of Sciences]

[28] Imre L. (BME). 2007. A napenergia-hasznosítás távlati feladatai, a nem kutatott területek, meg nem oldott problémák [English: Long-term tasks regarding solar energy utilization; unexplored fields, unsolved problems], Budapest

[29] European Wind Energy Association: The Economics of Wind Energy. www.ewea. org

[30] Bíróné Kircsi A., Tóth P. 2008. A szélenergia-hasznosítás jövője 2020-ig Magyarországon. [English: Future of wind energy utilization in Hungary until 2020], Budapest

[31] Bíróné Kircsi A., Tóth P. 2017. A szélenergia hasznosítás helyzete (English: State of wind energy utilization)

[32] MTA Energetikai Bizottság. Megújuló Energetikai Technológiák Albizottsága: A hazai megújuló energetikai potenciál reális értékeinek közelítő meghatározása a vízenergia hasznosítás területén [English: Hungarian Academy of Sciences. 2003. Approximation of the realistic value of the Hungarian renewable energy potential within the field of hydro energy utilization]

[33] Nemzeti Fejlesztési Minisztérium (NFM). Magyarország Megújuló Energia Hasznosítási Cselekvési Terve a 2020-ig terjedő megújuló energiahordozói felhasználás alakulásáról. [English: Ministry of National Development. Action Plan - Renewable Energy Utilization in Hungary until 2020, about the current state of utilization], Budapest, 2010. december 
[34] Unk J. (PYLON Kft.) Helyzetkép a hazai kis vízerőmúvekről - Előadás a VI. ENERGOexpo Nemzetközi Energetikai Konferencián 2008. szept. 23-25. [English: Current state of low-capacity hydropower plants in Hungary - Lecture]

[35] Pecznik P. (Világ Bank - GM - FVM Múszaki Intézet), Zsuffa L. (EKFM Ltd.), Unk J. (PYLON Ltd.) A biomassza potenciális felhasználása Magyarországon; Területi energiafelhasználások felmérése, közép és hosszú távú prognózisa. (English: Potential use of biomass in Hungary; exploring the regional energy use and prognosticating for mid-and long-term) Gödöllő 1999. március

[36] MTA: biomassza potenciál (English: Hungarian Academy of Science. Biomass Potential)

[37] Dinya L. Áttekintés a biomassza-alapú energiatermelés helyzetéról [English: Overview of the current state of biomass-based energy production] Gyöngyös, Károly Róbert Főiskola - Bioenergetikai Tudáskp. 2008.

[38] MEH-PYLON - Unk J. és munkacsoportja: Nemzeti Megújuló Energiahasznosítási Cselekvési Terv (NMCST) háttértanulmányai "A", „B", "C" kötet: Hasznosítható megújuló energiaátalakítási technológiák, megújuló energiapotenciálok, gazdasági-benchmark technológiák GREEN-X modell szerinti számításai, alapforgatókönyvek, változatok. Budapest, 2010. május. A támogatás politikai téma szerzői: Unk Jánosné, Kapros Zoltán, Mészáros Géza [English: Unk J. and working group: Primary Studies of Action Plan for National Renewable Energy Use - Calculations and scenarios using the GREEN-X model for renewable energy technologies and potentials]

[39] Lorberer Á. (VITUKI) 2004. A geotermális energiahasznosítás hazai fejlesztési koncepciója [English: Lorberer Á. 2004. Conception of the development of geothermal energy utilization in Hungary], Budapest

[40] EMT Erdélyi magyar Múszaki Tudományos Társaság ÉPKO 2017 konferencia, Csíksomlyó, Unk J. A Kárpát-medence térségére javasolható Geotermikus energiabázisú, hatékonyabb erőmúvi technológiák, példák. [English: Unk J. Power plant-base geothermal energy technologies recommended in Hungary - Conference in Csiksomlyó, 2017]

Open Access statement. This is an open-access article distributed under the terms of the Creative Commons Attribution 4.0 International License (https:/ / creativecommons.org/ licenses/by/4.0/), which permits unrestricted use, distribution, and reproduction in any medium, provided the original author and source are credited, a link to the CC License is provided, and changes - if any - are indicated. (SID_1) 